\title{
KAPASITAS ANTIOKSIDAN DAN KADAR FENOLIK TOTAL DALAM SARI BUAH MENGKUDU TERFERMENTASI
}

\author{
Anak Agung Sagung Desy Dwi Martayani*, Ni Made Suaniti dan Wahyu Dwijani Sulihingtyas \\ Program Studi Kimia FMIPA Universitas Udayana, Bukit Jimbaran, Badung, Bali 80361 \\ *Email: tujungdesy@yahoo.com
}

\begin{abstract}
ABSTRAK
Penelitian ini tentang pengujian kapasitas antioksidan dan kandungan fenolik total sari buah mengkudu terfermentasi dengan penambahan sari jahe dan gula merah. Tujuan penelitian ini adalah untuk menganalisis perubahan kapasitas antioksidan dan kandungan fenolik total dalam sari buah mengkudu sebelum dan setelah difermentasi selama beberapa hari. Kapasitas antioksidan dalam sari buah mengkudu semakin kecil setelah fermentasi yaitu dari 38,10 mgGAE/100 g (sebelum ditambahkan sari jahe, gula merah, tanpa difermentasi) menjadi 30,18; 28,68; dan 23,97 mgGAE/100 g berturut-turut setelah 2, 4, dan 6 hari fermentasi. Penurunan juga terjadi pada kadar fenolik total yaitu dari 54,46 menjadi 45,54; 39,39; dan 34,82 mgGAE/100 g.
\end{abstract}

Kata kunci: buah mengkudu, Fermentasi, kapasitas antioksidan, total fenol

\begin{abstract}
This research paper is about the the antioxidant capacity and total phenolic content of fermented noni added with ginger dan brown sugar. The aim of research was to analize the antioxidant capacity and total phenolic content of noni juice with and without fermentation. The antioxidant capacity of noni juice decreased which were 38.10 mgGAE/100g (before the addition of ginger and brown sugar without fermentation) to 30.18, 28.68 and 23.97 mgGAE/100g after 2, 4 and 6 days of fermentation respectively. The total phenolic content of noni juice also decreased after fermentation from 54.46 to $45.54,39.39$ and $34.82 \mathrm{mgGAE} / 100 \mathrm{~g}$.
\end{abstract}

Keywords: antioxidant capacity, fermentation, Noni fruit, total phenolic

\section{PENDAHULUAN}

Radikal bebas berperan dalam terjadinya penyakit degeneratif karena memiliki elektron bebas yang tidak berpasangan pada orbit terluarnya sehingga bersifat reaktif untuk bereaksi dengan molekul lain (Valko et al., 2006). Antioksidan adalah senyawa yang dapat menghambat reaksi dari radikal bebas di dalam tubuh dengan cara mendonorkan elektron kepada radikal bebas tersebut (Bahalawan dan Sjabana, 2002).

Pencegahan terhadap penyakit yang ditimbulkan akibat kerusakan oksidatif dapat dilakukan dengan mengkonsumsi makanan maupun minuman yang mengandung antioksidan (Winarsi, 2007). Salah satu contoh bahan makanan dan minuman yang mengandung antioksidan alternatif adalah buah mengkudu.

Sari buah mengkudu dikenal sebagai air emas karena mempunyai berbagai macam khasiat karena mengandung zat aktif, salah satunya sebagai antioksidan. Hasil penelitian membuktikan bahwa buah mengkudu mempunyai aktivitas antioksidan yang cukup besar karena mengandung berbagai macam senyawa antioksidan, yaitu asam askorbat, mineral selenium, rutin dan Americanin A (Solomon, 1998). Meskipun buah mengkudu mempunyai kelimpahan yang tinggi di Indonesia namun faktanya tingkat konsumsi buah mengkudu masih belum optimal. Ini dikarenakan adanya asam kaproat dalam buah mengkudu yang mengakibatkan aroma tidak sedap sehingga masyarakat menjadi enggan mengkonsumsi buah 
mengkudu (Bangun dan Sarwono, 2002), maka dilakukan upaya menghilangkan bau buah mengkudu melalui fermentasi sari buahnya.

Menurut penelitian yang telah dilakukan oleh Zackyah et al. (2014) tentang buah mengkudu sebagai antioksidan pada produksi minuman fungsional yoghurt dengan melakukan fermentasi non alkoholik tanpa menambahkan mikroba spesifik menunjukkan bahwa kandungan asam kaproat yang menyebabkan aroma tidak sedap menurun, namun fermentasi tersebut juga mengakibatkan penurunan kadar asam askorbat sehingga kemampuannya sebagai antioksidan ikut menurun.

Oleh karena itu pada penelitian ini dilakukan fermentasi yang berbeda yaitu dengan fermentasi alkoholik memanfaatkan khamir Saccharomyces cerevisiae dengan sifat fermentasi semi-anaerob. Selanjutnya dilakukan analisis kapasitas antioksidan dan kandungan total fenol sebelum dan setelah fermentasi pada waktu bervariasi.

\section{MATERI DAN METODE}

\section{Bahan}

Bahan-bahan yang digunakan dalam penelitian ini adalah buah mengkudu setengah matang dengan daging buah berwarna putih dan agak keras, akuades, gula merah, sari jahe,Saccharomyces cerevisiae, etanol p.a, larutan asam galat, DPPH, larutan folin-ciocalteu, dan $\mathrm{Na}_{2} \mathrm{CO}_{3} 5 \%$.

\section{Peralatan}

Peralatan yang digunakan dalam penelitian ini adalah seperangkat alat gelas, blender, penangas air, plat tetes, penyaring, timbangan, alat pendingin, kain kassa, pipet mikro, botol vial, termometer $100^{\circ} \mathrm{C}$, dan spektrofotometri UVVisible.

\section{Cara Kerja}

\section{Penyiapan Sampel dan Fermentasi}

Peralatan yang digunakan dalam penelitian ini adalah seperangkat alat gelas, blender, penangas air, plat tetes, penyaring, timbangan, alat pendingin, kain kassa, pipet mikro, botol vial, termometer $100^{\circ} \mathrm{C}$, dan spektrofotometri UV-
VisibleSebanyak $100 \mathrm{~g}$ buah mengkudu yang sudah dipilih kemudian dicuci bersih, lalu diblansir pada suhu $65^{\circ} \mathrm{C}$ selama 2 menit 30 detik. Kemudian ditambahkan $100 \mathrm{~mL}$ akuades dan diblender. Pembuatan sari buah mengkudu dilakukan sebanyak 5 kali untuk 5 perlakuan yang berbeda. Sebanyak $100 \mathrm{~mL}$ sari buah mengkudu masing-masing ditambahkan gula merah dan $2 \mathrm{~mL}$ sari jahe. Setelah itu difermentasi dengan menambahkan 0,2 mL $S$. cerevisiae. Setelah itu dilakukan fermentasi sesuai Tabel 1.

Tabel 1. Fermentasi Sari Buah Mengkudu

\begin{tabular}{cc}
\hline Kode Sampel & Fermentasi \\
\hline $\mathrm{M}_{2}$ & 2 hari \\
$\mathrm{M}_{3}$ & 4 hari \\
$\mathrm{M}_{4}$ & 6 hari \\
\hline
\end{tabular}

Fermentasi dilakukan secara semi-anaerob dengan wadah fermentor tertutup kasa steril dan diinkubasi pada suhu $30^{\circ} \mathrm{C}$. Dibuat juga sampel dengan kode $\mathrm{M}_{1}$ yaitu berisi sari buah mengkudu, gula merah dan sari jahe serta tidak difermentasi.

\section{Uji Kapasitas Antioksidan Secara Spektrofoto- metri}

Sari buah mengkudu hasil fermentasi maupun sari buah mengkudu kontrol dipipet masing-masing sebanyak $1 \mathrm{~mL}$, kemudian diencerkan dengan etanol p.a pada labu ukur 25 $\mathrm{mL}$ sehingga kadarnya $4 \% \mathrm{v} / \mathrm{v}$. Selanjutnya dibuat variasi konsentrasi dengan dipipet masing-masing sebanyak 100, 150, 200, 300 dan $400 \mu \mathrm{L}$, kemudian diencerkan dengan etanol p.a hingga volume $1 \mathrm{~mL}$, sehingga didapatkan konsentrasinya berturut-turut 0,$4 ; 0,6 ; 0,8 ; 1,2$ dan $1,6 \% \mathrm{v} / \mathrm{v}$. Masing-masing variasi konsentrasi ini direaksikan dengan $1 \mathrm{~mL}$ DPPH $0,1 \mathrm{mM}$ maka perbandingan sampel dan DPPH adalah 1:1 dan diinkubasi selama 30 menit. Dilakukan pengukuran absorbansi pada panjang gelombang 517nm untuk mendapatkan nilai Inhibition Concentration 50\% $\left(\mathrm{IC}_{50}\right)$ dan kapasitas antioksidan yang dihitung sebagai milligram asam galat per 100 gram sampel dengan memasukkan nilai absorbansi sampel pada persamaan regresi linear yang diperoleh dari kurva kalibrasi asam galat.

Larutan standar asam galat $1 ; 1,5 ; 2 ; 3$; dan $4 \mathrm{mg} / \mathrm{L}$ masing-masing dipipet sebanyak $1 \mathrm{ml}$, kemudian ditambahkan $1 \mathrm{ml}$ larutan DPPH 0,1mM 
dalam botol vial. Setelah itu diinkubasi selama 30 menit dan diukur serapannya pada panjang gelombang maksimum.

\section{Penentuan Kadar Fenolik Total}

Larutan standar asam galat $10 ; 20 ; 30 ; 40$; dan $50 \mathrm{mg} / \mathrm{L}$ masing-masing dipipet $0,4 \mathrm{ml}$ kemudian ditambahkan $0,4 \mathrm{ml}$ larutan folinciocalteu dan $3,2 \mathrm{ml} \mathrm{Na}_{2} \mathrm{CO}_{3} 5 \%$. Setelah itu diinkubasi selama 1 jam dan diukur serapannya pada panjang gelombang maksimum.

Larutan stock sampel masing-masing dipipet sebanyak $0,4 \mathrm{~mL}$ kemudian ditambahkan 0,4mL larutan Folin-Ciocalteu dan 3,2mL larutan $\mathrm{Na}_{2} \mathrm{CO}_{3} 5 \%$. Larutan diinkubasi selama 1 jam dan disentrifugasi $3000 \mathrm{rpm}$ selama 15 menit dan diambil supernatannya untuk dibaca absorbansinya pada panjang gelombang $765 \mathrm{~nm}$. Kadar ekstrak fenolik dihitung sebagai milligram asam galat per 100 gram sampel dengan memasukkan nilai absorbansi sampel pada persamaan regresi linear yang diperoleh dari kurva kalibrasi asam galat.

\section{HASIL DAN PEMBAHASAN}

\section{Pengukuran $\mathrm{IC}_{50}$ sampel}

Inhibition concentration $50 \%$ dihitung sebagai konsentrasi sampel yang dapat meredam radikal DPPH sebanyak 50\% diukur pada panjang gelombang 517,0nm. Nilai $\mathrm{IC}_{50}$ masing-masing sampel seperti ditunjukkan dalam Tabel 2.

Tabel 2. Nilai $\mathrm{IC}_{50}$ sari buah mengkudu

\begin{tabular}{cc}
\hline Kode sampel & $\mathrm{IC}_{50} \% \mathrm{v} / \mathrm{v}$ \\
\hline $\mathrm{M}_{1}$ & 0,83 \\
$\mathrm{M}_{2}$ & 0,87 \\
$\mathrm{M}_{3}$ & 1,03 \\
$\mathrm{M}_{4}$ & 1,23 \\
\hline
\end{tabular}

Dari Tabel 2 dapat dilihat bahwa kontrol dan sampel memiliki $\mathrm{IC}_{50}$ yang berbeda-beda. $\mathrm{IC}_{50}$ diatas menyatakan konsentrasi yang dibutuhkan oleh sampel untuk meredam 50\% DPPH $0,1 \mathrm{mM}$ dengan perbandingan sampel dan DPPH sebesar 1:1. Semakin besar $\mathrm{IC}_{50}$ nya maka semakin besar konsentrasi yang diperlukan untuk meredam radikal DPPH.
Kontrol $2\left(\mathrm{M}_{2}\right)$ dapat dikatakan sebagai sari buah mengkudu yang paling aktif meredam radikal bebas dibandingkan dengan kontrol $1\left(\mathrm{M}_{1}\right)$ dan sampel yang telah difermentasi, hal ini disebabkan karena kontrol 2 dilakukan penambahan sari jahe dan tidak difermentasi. Sari jahe dengan kandungan utama gingerol dan shogaol yang memiliki kemampuan sebagai antioksidan (Masuda et al., 2004), sehingga aktivitas antioksidan pada kontrol 2 lebih tinggi daripada kontrol 1 yang tidak dilakukan penambahan sari jahe.

Pada sampel 1, 2, dan 3 semakin lama hari fermentasinya maka semakin tinggi $\mathrm{IC}_{50}$ nya, hal ini menandakan bahwa sampel semakin berkurang kemampuannya sebagai antioksidan yang ditunjukkan dengan semakin banyak konsentrasi yang diperlukan untuk meredam 50\% radikal bebas. Fermentasi juga mempengaruhi nilai $\mathrm{IC}_{50}$ dari sampel karena dengan perlakuan fermentasi memungkinkan senyawa yang berperan antioksidan mengalami oksidasi.

\section{Pengukuran Absorbansi Standar Asam Galat}

Data absorbansi standar asam galat yang diukur pada panjang gelombang 517,0nm untuk meredam $0,1 \mathrm{mM}$ DPPH dengan perbandingan sampel dan DPPH 1:1 disajikan pada Gambar 1.

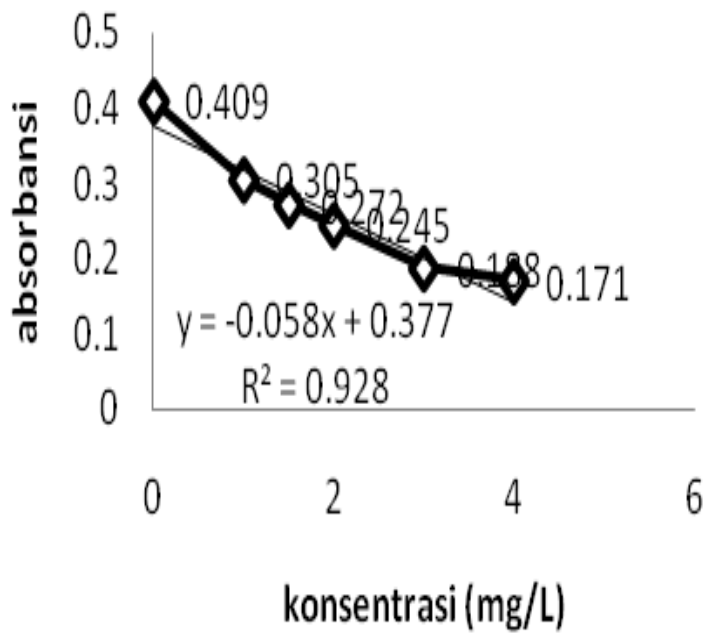

Gambar 1. Kurva kalibrasi standar asam galat terhadap peredaman DPPH 
Pada Gambar 1 terlihat bahwa persamaan regresi linearnya $y=-0,0584 x+0,377$ dengan $R^{2}=$ 0,9282 . Nilai $R^{2}$ yang mendekati 1 menyatakan bahwa data di atas memiliki linearitas yang tinggi.

\section{Kapasitas Antioksidan}

Uji kapasitas antioksidan adalah sebuah metode pengujian untuk mengukur jumlah radikal yang ditangkap oleh antioksidan dengan menggunakan standar. Pada penelitian ini digunakan standar asam galat sehingga kapasitas antioksidan dinyatakan dalam mgGAE/100g sampel.

Hasil kapasitas antioksidan sari buah mengkudu seperti dperlihatkan dalam Tabel 3 . Hasilnya menunjukkan bahwa sampel 1 sampai 3 mengalami penurunan kapasitas antioksidan akibat masa inkubasi fermentasi yang berbeda dan menandakan bahwa fermentasi juga mempengaruhi kapasitas antioksidan.

Tabel 3. Kapasitas Antioksidan Sari Buah Mengkudu

Kode sampel Kapasitas antioksidan
(mgGAE/100g)

\begin{tabular}{ll}
\hline $\mathrm{M}_{1}$ & 38,10 \\
$\mathrm{M}_{2}$ & 30,18 \\
$\mathrm{M}_{3}$ & 28,68 \\
$\mathrm{M}_{4}$ & 23,97 \\
\hline
\end{tabular}

Lama fermentasi mengakibatkan hilangnya beberapa komponen antioksidan akibat reaksi oksidasi enzimatis, dimana semakin lama waktu fermentasinya maka kapasitas antioksidannya semakin menurun (Kukthar, 2007).

\section{Penentuan Kadar Fenolik Total}

Hasil dari pengukuran absorbansi sejumlah standar asam galat dengan seri konsentrasi pada panjang gelombang $760 \mathrm{~nm}$ dipaparkan pada Gambar 2.

Penentuan kandungan fenolik total sari buah mengkudu ditentukan dengan memasukkan absorbansi sampel pada kurva kalibrasi. Hasil menunjukkan bahwa kandungan fenolik total sari buah mengkudu yang telah difermentasi mengalami penurunan. Hal ini menandakan bahwa fermentasi mempengaruhi kandungan total fenol, dimana semakin lama waktu fermentasinya maka semakin kecil kandungan total fenolnya karena fenol dalam sampel semakin banyak yang teroksidasi. Hasilnya seperti ditunjukkan dalam Tabel 4.

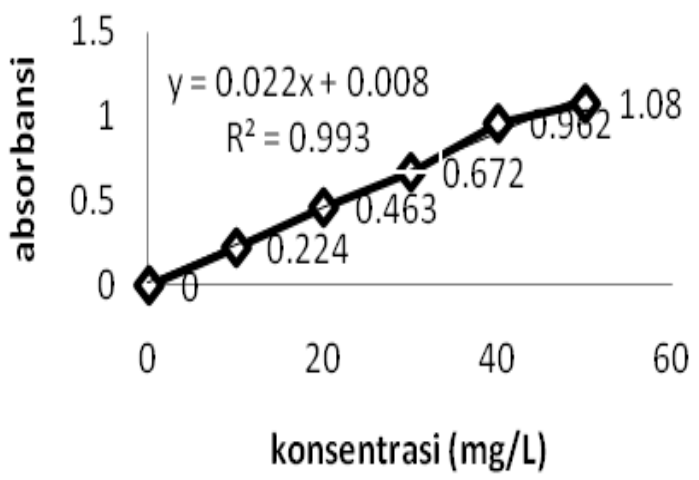

Gambar 2. Kurva Kalibrasi Standar Asam Galat terhadap pereaksi Folin-Ciocalteu

Zapsalis (1985) menyatakan bahwa senyawa fenol merupakan senyawa yang bersifat antioksidan dapat teroksidasi dengan adanya cahaya, panas dan oksigen. Senyawa fenolik mengalami oksidasi enzimatis selama fermentasi yaitu oksidasi oleh oksigen melalui bantuan enzim sebagai katalisis akan mengubah gugus hidroksil pada polifenol menjadi keton (Mardiah, 1996).

Tabel 4. Kadar Fenolik Total Sari Buah Mengkudu

\begin{tabular}{cc}
\hline Kode sampel & $\begin{array}{c}\text { Kadar Fenolik Total } \\
(\mathrm{mgGAE} / 100 \mathrm{~g})\end{array}$ \\
\hline $\mathrm{M}_{1}$ & 54,46 \\
$\mathrm{M}_{2}$ & 45,54 \\
$\mathrm{M}_{3}$ & 39,39 \\
$\mathrm{M}_{4}$ & 34,82 \\
\hline
\end{tabular}

Data Tabel 3 dan 4 terlihat bahwa kapasitas antioksidan berbanding lurus dengan kadar fenolik total, semakin tinggi kandungan fenolik total maka semakin tinggi kapasitas antioksidannya karena fenol merupakan salah satu senyawa yang berperan sebagai antioksidan. Hubungan antara kapasitas antioksidan dan fenolik total dipaparkan pada Gambar 3 dimana didapat nilai $\mathrm{R}^{2}=0,9959$ menunjukkan bahwa kapasitas antioksidan dan kadar fenolik total memberikan hubungan linear. 


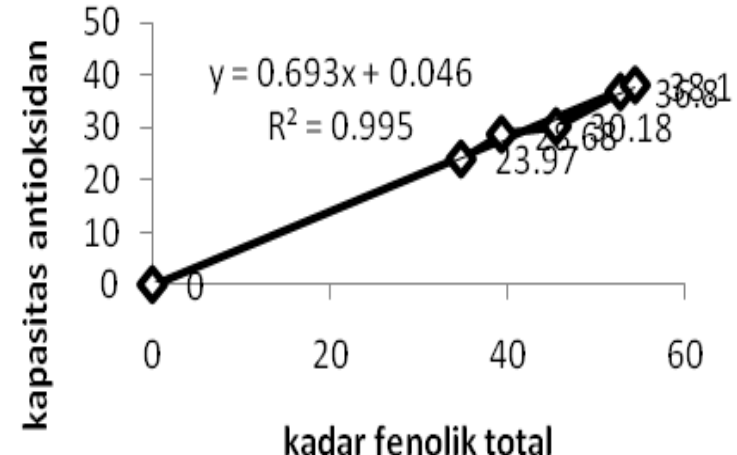

Gambar 3. Kurva Hubungan Kapasitas Antioksidan Dan Kadar Fenolik Total Sari Buah Mengkudu

\section{SIMPULAN DAN SARAN}

\section{Simpulan}

1. Kapasitas antioksidan dalam sari buah mengkudu semakin kecil setelah fermentasi dari 38,10 (setelah ditambahkan sari jahe, gula merah, tanpa difermentasi) menjadi 30,18; 28,68 ; dan 23,97 $\mathrm{mgGAE} / 100 \mathrm{~g}$ masingmasing selama 2, 4, dan 6 hari fermentasi karena komponen antioksidan mengalami oksidasi enzimatis.

2. Kadar fenolik total dalam sari buah mengkudu semakin kecil setelah fermentasi dari 54,46 menjadi 45,54; 39,39; dan 34,82 mgGAE/100g (milligram gallic acid equivalent per $100 \mathrm{~g}$ sampel) akibat teroksidasinya gugus hidroksil pada fenol menjadi keton.

\section{Saran}

Perlu dilakukan penelitian dengan metode lain untuk menghilangkan bau buah mengkudu tanpa mengurangi kapasitas antioksidannya.

\section{UCAPAN TERIMA KASIH}

Penulis mengucapkan terimakasih kepada Bapak I. B. Widnyana Yoga, S.TP., M.Si., seluruh dosen dan staf Program Studi Kimia Fakultas
MIPA Universitas Udayana atas bimbingan dan saran yang telah diberikan selama penelitian ini.

\section{DAFTAR PUSTAKA}

Bangun, A.P. dan Sarwono, B., 2002, Khasiat dan Manfaat Mengkudu, Edisi 1, Agromedia Pustaka, Jakarta

Kukhtar. H., 2007, Abstract of talk at International Millennium Tea Convention NewDelhi, India Department of Dermatology Case Western Reserve University Cleveland, $\mathrm{OH}-$ 44106, USA

Mardiah, E., 1996, Penentuan aktivitas dan inhibisi enzim polifenol oksidase dari apel (Pyrus malus Linn.), Jurnal Kimia Andalas, 2: 2

Masuda, Y., Kikuzaki, H., Hisamoto, M., dan Nakatani, N., 2004, Antioxidant properties of ginger related compounds from ginger, Biofactors, 21: 293-296

Solomon, N., 1998, Noni Nature's Amazing Healer, Woodland Publ. Pleasant Grove, Utah, USA

Valko, M., Leibfritz, D., Moncol, J., Cronin, M., Mazur, M., and Telser, J., 2006, Free radicals and antioxidants in normal physiological functions and human disease, Int J Biochem Cell Bio, 139 (1): 44-84

Winarsi, H., 2007, Antioksidan Alami dan Radikal Bebas, Kanisius, Yogjakarta

Zapsalis, C. A. Beck, 1985, Food Chemistry and Nutritional Biochemistry. John Willey and Sons, New York, p. 453-454

Zackiyah., Dwiyanti, G., dan Supriyanti, F. M., 2014, Buah Mengkudu (Morinda Citrifolia L) Sebagai Sumber Antioksidan Pada Produksi Minuman Fungsional Yoghurt, Prosiding Seminar Nasional Sanis dan Pendidikan Sains IX, Salatiga, 5 (1): 20870922 